\title{
Fluoxetine induces alkalinization of astroglial cytosol through stimulation of sodium-hydrogen exchanger 1: dissection of intracellular signaling pathways
}

\author{
Jienan Ren ${ }^{1+}$, Dan Song ${ }^{1+}$, Qiufang Bai ${ }^{1}$, Alexei Verkhratsky ${ }^{2,3,4}$ and Liang Peng ${ }^{1 *}$ \\ ${ }^{1}$ Laboratory of Brain Metabolic Diseases, Institute of Metabolic Disease Research and Drug Development, China Medical University, Shenyang, China \\ ${ }^{2}$ Faculty of Life Science, The University of Manchester, Manchester, UK \\ ${ }^{3}$ Achucarro Center for Neuroscience, IKERBASQUE, Basque Foundation for Science, Bilbao, Spain \\ ${ }^{4}$ University of Nizhny Novgorod, Nizhny Novgorod, Russia
}

Edited by:

Vladimir Parpura, University of

Alabama, USA

Reviewed by:

Luca Steardo, Sapienza University

of Rome, Italy

Marko Kreft, University of Ljubljana,

Slovenia

\section{*Correspondence:}

Liang Peng, Laboratory of Brain

Metabolic Diseases, Institute of

Metabolic Disease Research and

Drug Development, China Medical

University, No. 77, Puhe Road,

Shenyang North New Area,

Shenyang, 110122, China

e-mail: hkkid08@yahoo.com

${ }^{\dagger}$ These authors have contributed

equally to this work.
Clinical evidence suggest astrocytic abnormality in major depression (MD) while treatment with anti-psychotic drugs affects astroglial functions. Astroglial cells are involved in $\mathrm{pH}$ homeostasis of the brain by transporting protons (through sodium-proton transporter 1. NHE1, glutamate transporters EAAT1/2 and proton-lactate co-transporter MCT1) and bicarbonate (through the sodium-bicarbonate co-transporter NBC or the chloridebicarbonate exchanger $\mathrm{AE}$ ). Here we show that chronic treatment with fluoxetine increases astroglial $\mathrm{pH}_{i}$ by stimulating NHE1-mediated proton extrusion. At a clinically relevant concentration of $1 \mu \mathrm{M}$, fluoxetine significantly increased astroglial $\mathrm{pH}_{i}$ from 7.05 to 7.34 after 3 weeks and from 7.18 to 7.58 after 4 weeks of drug treatment. Stimulation of NHE1 is a result of transporter phosphorylation mediated by several intracellular signaling cascades that include MAPK/ERK $1 / 2$, PI3K/AKT and ribosomal S6 kinase (RSK). Fluoxetine stimulated phosphorylation of ERK $1 / 2, A K T$ and RSK in a concentration dependent manner. Positive crosstalk exists between two signal pathways, MAPK/ERK ${ }_{1 / 2}$ and PI3K/AKT activated by fluoxetine since ERK $1 / 2$ phosphrylation could be abolished by inhibitors of PI3K, LY294002 and AKT, triciribine, and AKT phosphorylation by inhibitor of MAPK, U0126. As a result, RSK phosphorylation was not only inhibited by U0126 but also by inhibitor of LY294002. The NHE1 phoshorylation resulted in stimulation of NHE1 activity as revealed by the $\mathrm{NH}_{4} \mathrm{Cl}$-prepulse technique; the increase of $\mathrm{NHE} 1$ activity was dependent on fluoxetine concentration, and could be inhibited by both U0126 and LY294002. Our findings suggest that regulation of astrocytic $\mathrm{pH}_{i}$ and brain $\mathrm{pH}$ may be one of the mechanisms underlying fluoxetine action.

Keywords: astrocytes, fluoxetine, $\mathrm{pH}_{\mathrm{i}}, \mathrm{NHE}, \mathrm{ERK}_{1 / 2}, \mathrm{AKT}$

\section{INTRODUCTION}

The most primary and fundamental astroglial function lies in providing the homeostasis of the central nervous system (CNS). Numerous molecular cascades expressed (often specifically) in astrocytes control interstitial concentration of principal ions, regulate movement and metabolism of major neurotransmitters, supply neurones with energy substrates and contribute to tissue defence through, for example, secreting scavengers of reactive oxygen species (Deitmer and Rose, 2010; Rose et al., 2013; Verkhratsky et al., 2015). Astroglial cells are involved in regulation of interstitial $\mathrm{pH}$ by transporting both protons (mostly through sodium-proton transporter 1, NHE1, glutamate transporters EAAT1/2 and proton-lactate co-transporter MCT1) and bicarbonate (through the sodium-bicarbonate co-transporter $\mathrm{NBC}$ or the chloride-bicarbonate exchanger AE; see (Deitmer and Chesler, 2009; Deitmer and Rose, 2010)). The NHE1 or a solute carrier family 9 member 1, SLC9A1 represents the major pathway for $\mathrm{H}^{+}$extrusion from astrocytes, in exchange for $\mathrm{Na}^{+}$; the NHE1 is electro-neutral antiporter with a stoichiometry $1 \mathrm{Na}^{+}: 1 \mathrm{H}^{+}$(Boedtkjer et al., 2012). Similarly to many other astroglial ion transporters NHE1 is regulated by a transmembrane $\mathrm{Na}^{+}$gradient being thus under control of astroglial $\mathrm{Na}^{+}$signaling (Kirischuk et al., 2012; Rose and Karus, 2013).

Astroglial dysfunction, pathological remodeling or reactivity contribute to pathogenesis of virtually all neurological diseases (Verkhratsky et al., 2013, 2014a) including neuropsychiatric disorders (Verkhratsky et al., 2014b). In particular evidence is constantly accumulating indicative of significant contribution of astroglia to major depression (MD). The number of glial fibrillary acidic protein (GFAP)-positive astroglial cells is conspicuously decreased in the brains of depressed patients (Rajkowska and Miguel-Hidalgo, 2007; McNally et al., 2008; Rajkowska and Stockmeier, 2013). Similarly, down-regulation of another astroglial marker, protein $S 100 \beta$, has been observed in the ventral prefrontal cortex of depressed suicide victims 
(Klempan et al., 2009). At the same time antidepressant treatment reversed these $\mathrm{MD}$-associated astroglial deficits as an increase in expression of astroglial markers GFAP, S100 $\beta$ and aldehyde dehydrogenase 1 family, member L1 (ALDH1L1) were revealed in the post-mortem analysis (Barley et al., 2009).

Deregulation of CNS $\mathrm{pH}$ homeostasis is a notable feature of mood disorders. In patients with bipolar disorders the intracellular $\mathrm{pH}\left(\mathrm{pH}_{i}\right)$ in neural cells is decreased in the euthymic state as measured by ${ }^{31}$ P-MRS (Kato et al., 1994; Iwanaga et al., 1996; Hamakawa et al., 2004). At the same time in MD patients treated with antidepessants the $\mathrm{pH}_{i}$ was not significantly different from the control group (Kato et al., 1998). Since astrocytes significantly contribute to regulation of both $\mathrm{pH}_{i}$ and $\mathrm{pH}$ of the interstitium we performed in depth analysis of the expression and function of astroglial NHE1 by treatment with most common antidepressant drug fluoxetine. We further studies intracellular pathways involved in fluoxetine-dependent regulation of NHE1.

\section{MATERIALS AND METHODS ASTROGLIAL CULTURES}

Primary cultures of astrocytes were prepared from the neopallia of the cerebral hemispheres of newborn CD-1 mice (all areas above and lateral to the lateral ventricles) by vortexing and filtering through nylon meshes with pore sizes of 80 and subsequently $10 \mu \mathrm{m}$ as previously described (Hertz et al., 1998; Hertz, 2012), with minor modifications (Li et al., 2009). The cells were planted in 60-mm Falcon Primaria dishes or on coverslips coated with polylysine. The culture medium was a Dulbecco's Medium Essential Medium (DMEM) with $7.5 \mathrm{mM}$ glucose, initially containing $20 \%$ horse serum, and the cultures were incubated at $37^{\circ} \mathrm{C}$ in a humidified atmosphere of $\mathrm{CO}_{2}$ /air $(5: 95 \%)$. The medium was exchanged with fresh medium of similar composition on day 3, and subsequently, every 3-4 days. From day 3, the serum concentration was reduced to $10 \%$, and after 2 weeks, $0.25 \mathrm{mM}$ dibutyryl cyclic AMP (dBcAMP) was included in the medium, which leads to a morphological and functional differentiation of astrocytes (Meier et al., 1991; Hertz et al., 1998). Characteristics, usage and advantages of these cultures has recently been authoritatively reviewed (Lange et al., 2012). Ontogenetic similarity with freshly isolated astrocytes in gene development has been reported by ourselves ( $\mathrm{Li}$ et al., 2012b); similarly there is evidence for identical drug-induced changes in gene expression between in vitro and in vivo assessed astrocytes (Li et al., 2012a; Song et al., 2012).

\section{WESTERN BLOTTING}

The protein content was determined in the homogenates by the Lowry method (Lowry et al., 1951), using bovine serum albumin (BSA) as the standard. Samples containing $75 \mu \mathrm{g}$ protein were applied on slab gels of $10 \%$ polyacrylamide. After transfer to nitrocellulose membranes, the samples were blocked by $5 \%$ skimmed milk powder in TBS-T for $1 \mathrm{~h}$, and the polyvinylidene difluoride (PVDF) membranes were incubated with the first antibody, specific to specific to p-ERK, ERK, p-ribosomal S6 kinase (RSK) or $\beta$-actin for $2 \mathrm{~h}$ at room temperature, or specific to p-AKT or AKT overnight at $4^{\circ} \mathrm{C}$. After washing, the blots were incubated with peroxidase-conjugated affinity-purified goat-anti-mouse or goat-anti-rabbit horseradish antibody for $2 \mathrm{~h}$. Staining was visualized by ECL detection reagents. Digital images obtained using Gel-Imaging System (Tanon 4200, Shanghai, China). Optical density for each band was quantified using the Window AlphaEase TM FC 32-bit software.

\section{IMMUNOPRECIPITATION AND WESTERN BLOTTING FOR NHE1}

The phosphorylation level of NHE1 was determined by immunoprecipitation with an antibody recognizing the phosphoSer 14-3-3 which binds to p-NHE1 as previously reported (Snabaitis et al., 2006; Luo et al., 2007). After homogenization, whole cell lysates $(1,000 \mu \mathrm{g})$ were incubated with $4 \mu \mathrm{l}$ of antimouse phospho-Ser 14-3-3 protein binding motif antibody for $12 \mathrm{~h}$ at $4^{\circ} \mathrm{C}$. Thereafter $50 \mu \mathrm{l}$ of washed Protein A/G PLUSagarose bead slurry was added, and the mixture was incubated for another $2 \mathrm{~h}$ at $4^{\circ} \mathrm{C}$. The agarose beads were collected by pulsing centrifuge ( $5 \mathrm{~s}$ in the microcentrifuge at $14,000 \mathrm{~g}$ ), the supernatant drained off and the beads boiled for $5 \mathrm{~min}$. Thereafter, the supernatant was collected by pulsing centrifuge and the entire immunoprecipitates were subjected to $8 \%$ SDSpolyacrylamide gel electrophoresis (PAGE). After transfer to PVDF memebranes, the membranes were incubated with the antibody specific to NHE1 at a 1:500 dilution overnight at $4^{\circ} \mathrm{C}$ and anti-mouse antibody at a 1:2000 dilution for $2 \mathrm{~h}$ at room temperature.

\section{MONITORING OF pH}

The fluorescent $\mathrm{pH}$-sensitive indicator BCECF-AM and an Olympus IX71 live cell imaging fluorescence microscope (Tokyo, Japan) were used to detect $\mathrm{pH}_{i}$ in individual cells as described by Grant and Acosta (1997) and Manning and Sontheimer (1999). After washing with 4-(2-hydroxyethyl)-1piperazineethanesulfonic acid (HEPES) buffer $(\mathrm{NaCl}: 140 \mathrm{mM}$; $\mathrm{KCl}: 5.36 \mathrm{mM} ; \mathrm{MgSO}_{4}$ : $0.81 \mathrm{mM} ; \mathrm{CaCl}_{2}$ : $1.27 \mathrm{mM} ; \mathrm{KH}_{2} \mathrm{PO}_{4}$ : $0.44 \mathrm{mM} ; \mathrm{Na}_{2} \mathrm{HPO}_{4}$ : $0.33 \mathrm{mM}$; glucose: $5.55 \mathrm{mM}$; HEPES: $20 \mathrm{mM}$; pH: 7.4), cells were loaded with $5 \mu \mathrm{M}$ BCECF-AM for $30 \mathrm{~min}$ at $37^{\circ} \mathrm{C}$. After washing twice with HEPES buffer, fluorescence was excited at 440 and $490 \mathrm{~nm}$ and emission monitored at $530 \mathrm{~nm}$. The fluorescence ratio $(490 / 440 \mathrm{~nm})$ was determined and calibrated to yield $\mathrm{pH}_{i}$ values by interpolation between the measured fluorescence ratios in a similar culture after $20 \mathrm{~min}$ of exposure to one of 3 calibration buffers $(\mathrm{pH}$ : 6.3, 6.9 or 7.5; KCl: $130 \mathrm{mM}$; $\mathrm{MgCl}_{2}$ : $1 \mathrm{mM}$; HEPES: $15 \mathrm{mM}$; MES: $15 \mathrm{mM})$. The calibration buffer also contained $56 \mu \mathrm{M}$ nigericin, an $\mathrm{H}^{+} / \mathrm{K}^{+}$exchanger, in order to equilibrate $\mathrm{pH}_{i}$ with extracellular $\mathrm{pH}$. Steady-state $\mathrm{pH}_{i}$ was determined as the average of five individual readings, each from six 20 s intervals (Song et al., 2008, 2013).

Acid challenge was performed by the $\mathrm{NH}_{4} \mathrm{Cl}$-prepulse technique (Boron and De Weer, 1976; McAlear and Bevensee, 2004). Cells were washed twice after BCECF-AM loading. Intracellular fluorescence ratio was determined at $25 \mathrm{~s}$ interval. Cells were bathed in HEPES buffer during the first four cycles, exposed to $20 \mathrm{mM} \mathrm{NH}_{4} \mathrm{Cl}$ added to the HEPES buffer with an 
equiosmolar reduction in the $\mathrm{NaCl}$ concentration during the next five cycles, and again incubated in HEPES buffer during the last twenty-seven $25 \mathrm{~s}$ intervals. Recovery of $\mathrm{pH}_{i}\left(\Delta \mathrm{pH}_{i}\right)$ during the last twenty-seven $25 \mathrm{~s}$ intervals was calculated by subtracting the $\mathrm{pH}_{i}$ after about $2 \mathrm{~min}$ (five cycles) exposure to $\mathrm{NH}_{4} \mathrm{Cl}$ from the $\mathrm{pH}_{i}$ measured every minute during the recovery for total of $10 \mathrm{~min}$, and NHE activity was determined as $\Delta \mathrm{pH}_{i} / \Delta \mathrm{t}$ (Song et al., 2008, 2013).

\section{CHEMICALS}

Chemicals for culture media and ABcAMP were purchased from Sigma (St. Louis, MO, USA) and horse serum from Invitrogen (Carlsbad, CA, USA). Fluoxetine, SB204741 (N-(1-methyl-5indolyl)- $\mathrm{N}^{\prime}$-(3-methyl-5-isothiazolyl) urea), triciribine hydrate and first antibodies, raised against $\beta$-actin were also purchased from Sigma (St. Louis, MO, USA). The U0126 (1,4-diamino-2,3dicyano-1,4-bis[2-aminophenylthio]butadiene) and LY294002 (2-(4-Morpholinyl)-8-phenyl-4H-1-benzopyran-4-one) were obtained from Calbiochem (La Jolla, CA, USA). Santa Cruz Biotechnology (Santa Cruz, CA, USA) supplied first antibodies, raised against ERK (K-23), sc-94, against phosphorylated ERK (E4), sc-7383, against phosphorylated AKT1/2/3 (Ser 473), sc-33437 and against phosphorylated RSK1/2 (Thr 359/Ser 363), sc-12898R. Protein A/G PLUS-agarose, sc-2003 were also purchased from Santa Cruz Biotechnology (Santa Cruz, CA, USA). The rabbit polyclonal antibody against AKT and phosphor-(Ser) 14-3-3 binding motif antibody were purchased from Cell Signaling Technology (Danvers, MA, USA). Chemicon (Temecula, CA, USA) supplied the first antibody, raised against NHE1. The second antibody goat anti-mouse IgG HRP conjugate (W4021) was from Promega (Madison, WI, USA) and goat anti-rabbit IgG HRP conjugate (sc-2004) from Santa Cruz Biotechnology (Santa Cruz, CA, USA). ECL detection reagents were from Amersham Biosciences, Buckinghamshire, UK. Invitrogen Corp. (Carlsbad, CA, USA) provided BCECF-AM, an acetoxymethyl (AM) ester of $2^{\prime}, 7^{\prime}$-bis(2-carboxyethyl)-5(6)-carboxyfluorescein (BCECF).

\section{STATISTICS}

Differences between multiple groups were evaluated by oneway analysis of variance (ANOVA) followed by Fisher's least significant difference (LSD) multiple comparison test for unequal replications. The level of significance was set at $P<0.05$.

\section{RESULTS}

\section{TREATMENT WITH FLUOXETINE INCREASES ASTROGLIAL $\mathrm{pH}_{i}$}

Chronic treatment with fluoxetine caused a concentrationand time-dependent intracellular alkalinization (Figure 1). In astrocytes exposed to $10 \mu \mathrm{M}$ fluoxetine for 3 days the $\mathrm{pH}_{i}$ inreased from $7.05 \pm 0.13(n=32)$ to $7.48 \pm 0.06$ $(n=32)$ after 3 days of treatment (Figure 1A). When cells were incubated with $1 \mu \mathrm{M}$ fluoxetine (which concentration is closer to therapeutically relevant) the $\mathrm{pH}_{i}$ did not change during the first week of treatment (Figure 1B), with a trend towards an increase after 2 weeks of treatment, which was not significant. After 3 and 4 weeks of treatment, $\mathrm{pH}_{i}$, however, increased significantly. Chronic treatment with $1 \mu \mathrm{M}$ fluoxetine

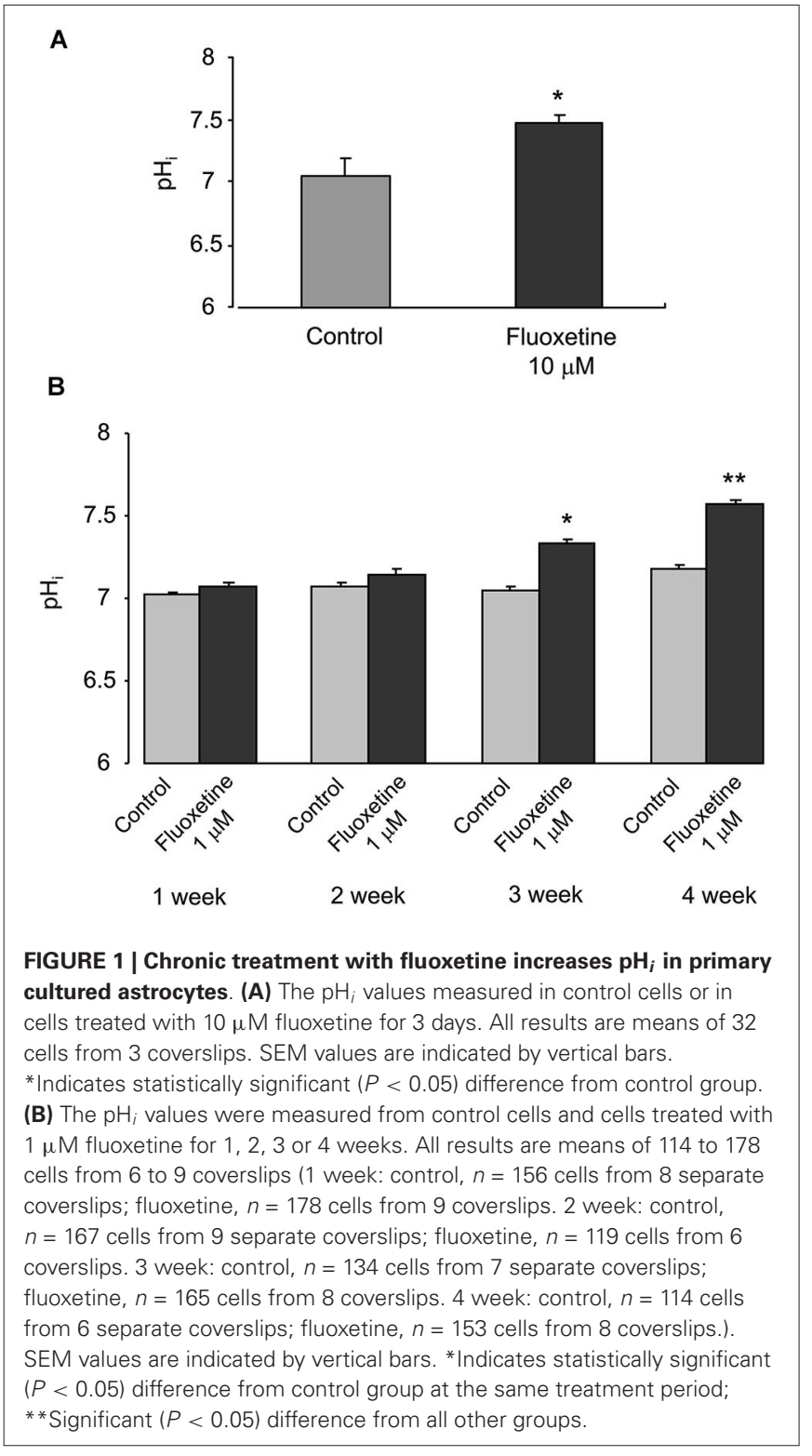

for 3 weeks increased $\mathrm{pH}_{i}$ from $7.05 \pm 0.02(n=134)$ to $7.34 \pm 0.02(n=165)$, and for 4 weeks from $7.18 \pm$ $0.02(n=114)$ to $7.58 \pm 0.01(n=153)$. Alkalinization of astroglial cytoplasm indicates, most likely, an increase in $\mathrm{H}^{+}$ extrusion which, arguably, may result from an increase in activity of NHE1 that represents the main pathway for proton efflux.

\section{FLUOXETINE INDUCES PHOSPHORYLATION OF NHE1}

The activity of NHE1 is known to be regulated by the transporter phosphorylation (Moor and Fliegel, 1999). This phosphorylation indeed takes place in cultured astrocytes exposed to fluoxetine, as demonstrated on Figure 2. Phosphorylation of NHE1 in cells treated with $10 \mu \mathrm{M}$ fluoxetine occurs rapidly reaching its maximum after $40 \mathrm{~min}$ and beginning to decline after $60 \mathrm{~min}$ (Figure 2A). Exposure of cultured astrocytes to $1 \mu \mathrm{M}$ fluoxetine also induced NHE1 phosphorylation (Figure 2B). 


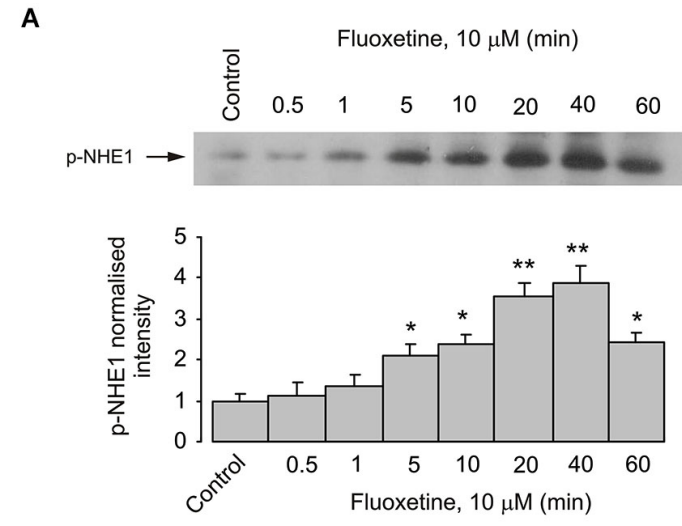

B

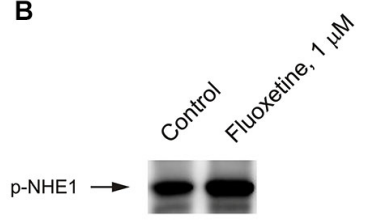

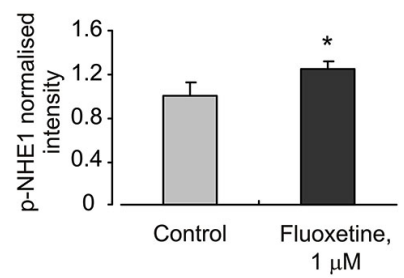

FIGURE 2 | Acute effect of fluoxetine on phosphorylation of NHE1 (A) Cells were incubated with $10 \mu \mathrm{M}$ fluoxetine for 0 (Control), 0.5, 1, 5, 10, 20,40 or $60 \mathrm{~min}$. Top: Immunoblots from representative experiments. Bands of $105 \mathrm{kDa}$ represent $\mathrm{p}-\mathrm{NHE} 1$. Similar results were obtained from three independent experiments. Bottom: Average NHE1 phosphorylation was quantified as scanned band intensity of NHE1 and normalized vs. band intensity from the control group. SEM values are indicated by vertical bars. *Indicates statistically significant $(P<0.05)$ difference from control, $0.5,1$, 20 and 40 min groups. ${ }^{*}$ Indicates statistically significant $(P<0.05)$ difference from control, 0.5, 1, 5, 10, and 60 min groups. (B) Cells were incubated with 0 (Control) or $1 \mu \mathrm{M}$ fluoxeine for $20 \mathrm{~min}$. Left: Immunoblots from representative experiments. Bands of $105 \mathrm{kDa}$ represent p-NHE1. Similar results were obtained from five independent experiments. Right: Average NHE1 phosphorylation was quantified as scanned band intensity of NHE1 and normalized vs. band intensity from the control group. SEM values are indicated by vertical bars. ${ }^{*}$ Indicates statistically significant $(P<$ 0.05) difference from control group.

\section{INTERACTION BETWEEN PI3K/AKT AND MAPK/ERK}

Pharmacological experiments described in previous section highlighted the possible role for PI3K/AKT and MAPK/ERK signaling pathways. Acute $(20 \mathrm{~min})$ treatment of astroglial cells with fluoxetine indeed triggered $\mathrm{ERK}_{1 / 2}$ phosphorylation in concentration-dependent manner (Figure 3). The fluoxetinedependent $\mathrm{ERK}_{1 / 2}$ phosphorylation was inhibited by $10 \mu \mathrm{M}$ U0126 (Figure 3A). Similarly $\mathrm{ERK}_{1 / 2}$ phopshorylation was suppressed by $25 \mu \mathrm{M}$ of LY294002, the PI3K inhibitor and by $10 \mu \mathrm{M}$ triciribine, the AKT inhibitor (Figure 3B) indicating signaling downstream of PI3K and AKT. Fluoxetine at 1 and $10 \mu \mathrm{M}$ increased AKT phosphorylation (Figure 4). Fluoxetinedependent AKT phosphoryation was abolished by $25 \mu \mathrm{M}$ LY294002 (Figure 4A) and by $10 \mu \mathrm{M}$ U0126 (Figure 4B).

\section{RSK PHOSPHORYLATION}

Fluoxetine also potentiated the phosphorylation of RSK in cultured astrocytes. Treatment of cells with 1 and $10 \mu \mathrm{M}$

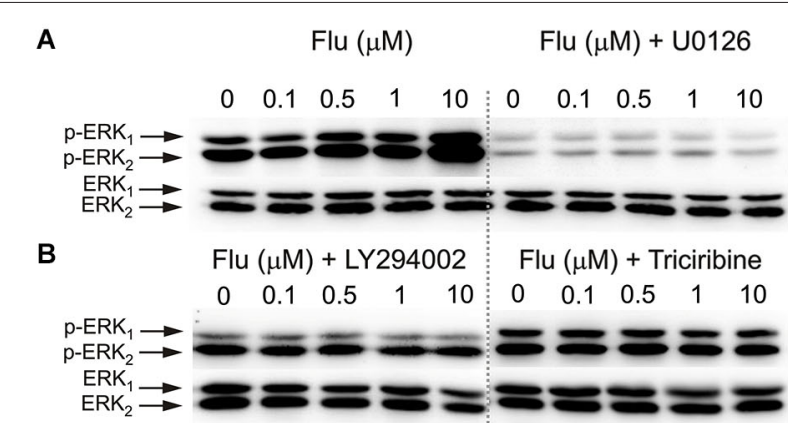

C
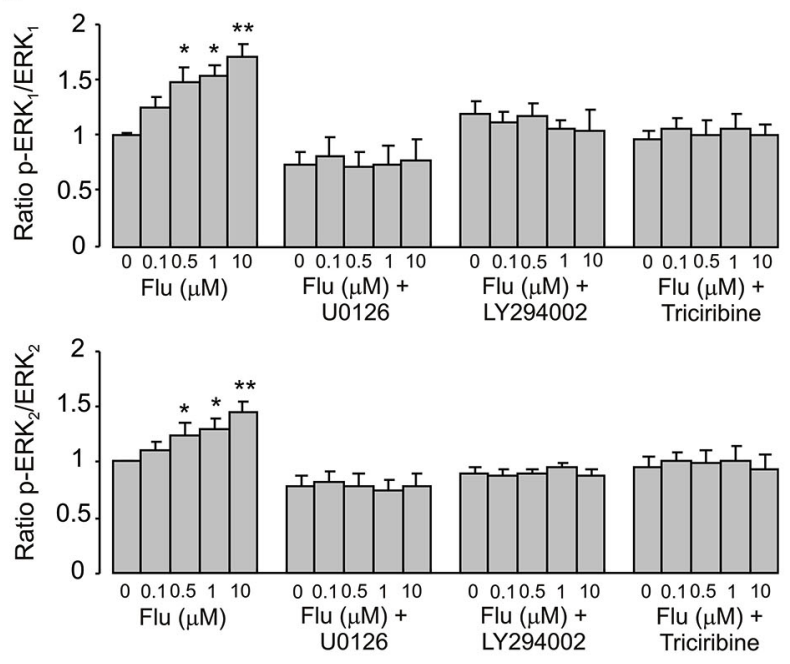

FIGURE 3 | ERK $1 / 2$ phosphorylation induced by fluoxetine requires MEK and AKT phosphorylation. (A,B) Immunoblots from representative experiments. (A) after pre-treatment in serum-free medium with or without $10 \mu \mathrm{M}$ of MEK inhibitor U0126, $25 \mu \mathrm{M}$ of PI3K inhibitor LY294002 or $10 \mu \mathrm{M}$ of AKT inhibitor triciribine (B) for $15 \mathrm{~min}$, cells were incubated for $20 \mathrm{~min}$ with 0 (Control), 0.1, 0.5, 1, $10 \mu \mathrm{M}$ fluoxetine. Bands of 44 and $42 \mathrm{kDa}$ represent $\mathrm{p}-\mathrm{ERK}_{1}$ (phosphorylated $E R K_{1}$ ) and $\mathrm{p}-\mathrm{ERK}_{2}$ (phosphorylated $E R K_{2}$ ), respectively (upper rows), or total $E R K_{1}$ and $E R K_{2}$ (lower rows). Similar results were obtained from five independent experiments. (C) Average ERK phosphorylation was quantified as ratios between $\mathrm{p}-\mathrm{ERK}_{1}$ and $\mathrm{ERK}_{1}$ (Top) and between $\mathrm{p}-\mathrm{ERK}_{2}$ and $\mathrm{ERK}_{2}$ (Bottom). Ratios between p-ERK 1 and $E R K_{1}$ or $p-E R K_{2}$ and ERK 2 were normalized to the control. SEM values are indicated by vertical bars. ${ }^{*}$ Indicates statistically significant $(P<$ 0.05 ) difference from control group, 0.1 and $10 \mu \mathrm{M}$ fluoxetine groups and fluoxetine plus U0126, LY294002 or triciribine groups. ${ }^{*}$ Indicates statistically significant $(P<0.05)$ difference from all other groups.

fluoxetine for $20 \mathrm{~min}$ induced a significant increase of RSK phosphorylation (Figure 5A). The level of RSK phosphorylation was significantly higher at $10 \mu \mathrm{M}$ than at $1 \mu \mathrm{M}$. The effect of fluoxetine was abolished by $10 \mu \mathrm{M}$ of U0126 and by $25 \mu \mathrm{M}$ of LY294002 (Figure 5B).

\section{NHE1 ACTIVITY}

Finally, we quantified NHE1 activity by measuring the rate of $\mathrm{pH}_{i}$ changes in individual cells following acidification induced by $20 \mathrm{mM} \mathrm{NH} 4 \mathrm{Cl}$ (Figure 6). In cells pretreated (for $20 \mathrm{~min}$ before measurements) with $0.1,1$, or $10 \mu \mathrm{M}$ of fluoxetine the $\mathrm{pH}_{i}$ recovered faster; and the rate of recovery increased with an increase in fluoxetine concentration (Figure 6A). 
A
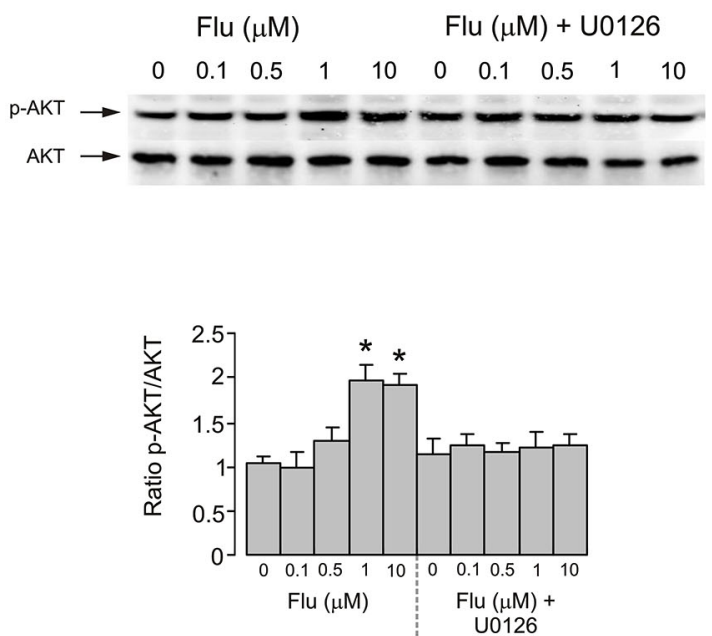

FIGURE 4 | AKT phosphorylation induced by fluoxetine requires MEK and PI3K phosphorylation. (A) After pretreatment in serum-free medium with or without $10 \mu \mathrm{M}$ of MEK inhibitor U0126 for $15 \mathrm{~min}$, cells were incubated for 20 min with 0 (Control), 0.1, 0.5, 1, $10 \mu \mathrm{M}$ fluoxetine. Top: Immunoblots from representative experiments. Bands of $60 \mathrm{kDa}$ represent p-AKT (Ser473) (upper rows), or total AKT (lower rows). Similar results were obtained in five independent experiments. Bottom: Average AKT phosphorylation was quantified as ratios between p-AKT and AKT and normalized to controls. SEM values are indicated by vertical bars. ${ }^{*}$ Indicates statistically significant $(P<$ 0.05) difference from control group, 0.1 and $0.5 \mu \mathrm{M}$ fluoxetine groups and
B
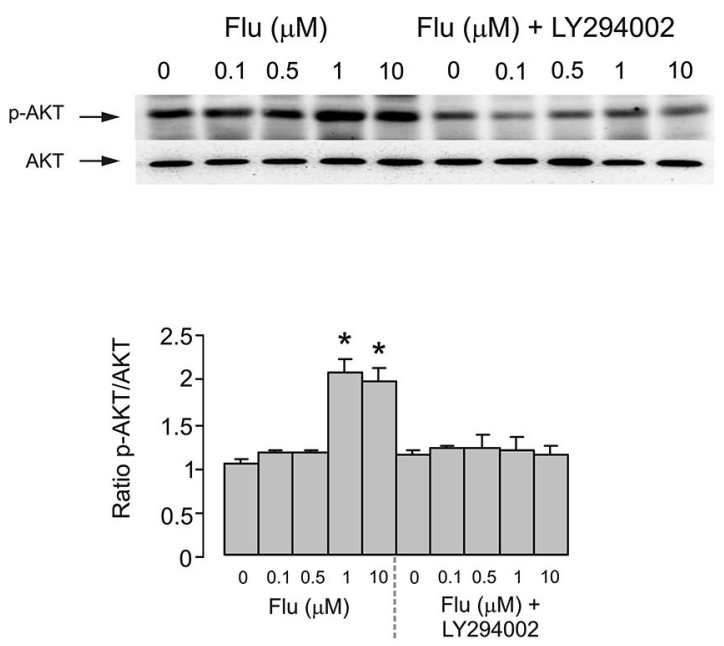

fluoxetine plus U0126 groups. (B) After pretreatment in serum-free medium with or without $25 \mu \mathrm{M}$ of PI3K inhibitor LY294002 for 15 min, cells were incubated for $20 \mathrm{~min}$ with 0 (Control), 0.1, 0.5, 1, $10 \mu \mathrm{M}$ fluoxetine. Top: Immunoblots from representative experiments. Bands of $60 \mathrm{kDa}$ represent p-AKT (Ser473) (upper rows), or total AKT (lower rows). Similar results were obtained in five independent experiments. Bottom: Average AKT phosphorylation was quantified as ratios between p-AKT and AKT and normalized to controls. SEM values are indicated by vertical bars. *Indicates statistically significant $(P<0.05)$ difference from control group, 0.1 and $0.5 \mu \mathrm{M}$ fluoxetine groups and fluoxetine plus LY294002 groups.
Fluoxetine-dependent increase in the activity of NHE1 was abolished by $200 \mathrm{nM} \mathrm{SB} 204741$, an antagonist of $5-\mathrm{HT}_{2 \mathrm{~B}}$ receptor, by $10 \mu \mathrm{M}$ of U0126 or by $25 \mu \mathrm{M}$ of LY294002 (Figure 6B).

\section{DISCUSSION}

Proton homeostasis and maintenance of intra- and extracellular $\mathrm{pH}$ in the brain is critically important for normal activity of neural cells and therefore for brain functions. Decrease in brain $\mathrm{pH}$ is associated with variety of pathological conditions, such as ischemia and epilepsy (Katsura and Siesjo, 1998). The $\mathrm{pH}$ of the extracellular fluid is affected by numerous $\mathrm{pH}$ regulating systems localized in neurones and neuroglia (for review, see McAlear and Bevensee, 2004; Deitmer and Chesler, 2009). Astroglia play an important role in regulation of interstitial $\mathrm{pH}$ and $\mathrm{pH}_{i}$ by their acid-loading, acid-extruding and bicarbonate transporting systems (McAlear and Bevensee, 2004; Deitmer and Chesler, 2009). Previously, we have reported that chronic treatment of astrocytes with three antibipolar drugs induced intracellular alkalization (Song et al., 2008, 2013). Specifically, lithium acutely stimulated proton efflux through NHE1 by direct action at the extracellular site (Song et al., 2008); whereas carbamazepine and valproic acid upregulated expression of electrogenic $\mathrm{Na}^{+} / \mathrm{HCO}_{3}{ }^{-}$co-transporter NBCe1/SLC4A4 (Song et al., 2013). In the present paper we performed systematic investigation of the effects of fluoxetine on $\mathrm{pH}$ regulation and intracellular signalling cascades in astrocytes.
In particular, we investigated effects of fluoxetine on (i) the $\mathrm{pH}_{i}$; (ii) the NHE1 phosphorylation; (iii) the interaction of MAPK/ERK $1 / 2$ and PI3K/AKT signal pathways; (iv) the RSK phosphorylation; and (v) the NHE1 activation following acidic stress.

As expected, both NHE1 and RSK were phosphorylated by acute treatment with fluoxetine, suggesting RSK was involved in NHE1 phosphorylation. This was suppressed by inhibition of either $\mathrm{MAPK} / \mathrm{ERK}_{1 / 2}$ or PI3K/AKT signaling pathways, indicating the interaction between them is required, although RSK is positioned downstream of $M A P K / E_{1 / 2}$ (Figure 7). The NHE1 activity measured by $\mathrm{NH}_{4} \mathrm{Cl}$ challenge was blocked by inhibition of either MAPK/ERK $1 / 2$ or PI3K/AKT pathway, and by an antagonist of $5-\mathrm{HT}_{2 \mathrm{~B}}$ receptor, demonstrated that the stimulation of NHE1 by fluoxetine is mediated by $5-\mathrm{HT}_{2 \mathrm{~B}}$ receptor. Previously, we reported that fluoxetine acts as agonists of $5-\mathrm{HT}_{2 \mathrm{~B}}$ receptors in astrocytes (Kong et al., 2002). All three 5- $\mathrm{HT}_{2}$ receptors, $5-\mathrm{HT}_{2 \mathrm{~A}}$, and $5-\mathrm{HT}_{2 \mathrm{~B}}$ and $5-\mathrm{HT}_{2 \mathrm{C}}$ receptors are $\mathrm{G}_{q / 11}$ protein-coupled, and stimulation of these receptors activates phospholipase C (PLC), thus generating diacyglycerol (DAG) and inositol 1,4,5-trisphosphate $\left(\mathrm{InsP}_{3}\right)$. The fluoxetine-induced and $5-\mathrm{HT}_{2 \mathrm{~B}}$ receptor-mediated $\mathrm{ERK}_{1 / 2}$ phosphorylation as well as the effect of fluoxetine on epidermal growth factor receptor (EGFR) phosphorylation could be abolished by (i) AG1478, an inhibitor of the EGFR tyrosine kinase and by (ii) GM6001, a potent and broad-based inhibitor of $\mathrm{Zn}^{2+}$-activated metalloproteinases (Li et al., 2008), suggesting the role of EGFR transactivation. 


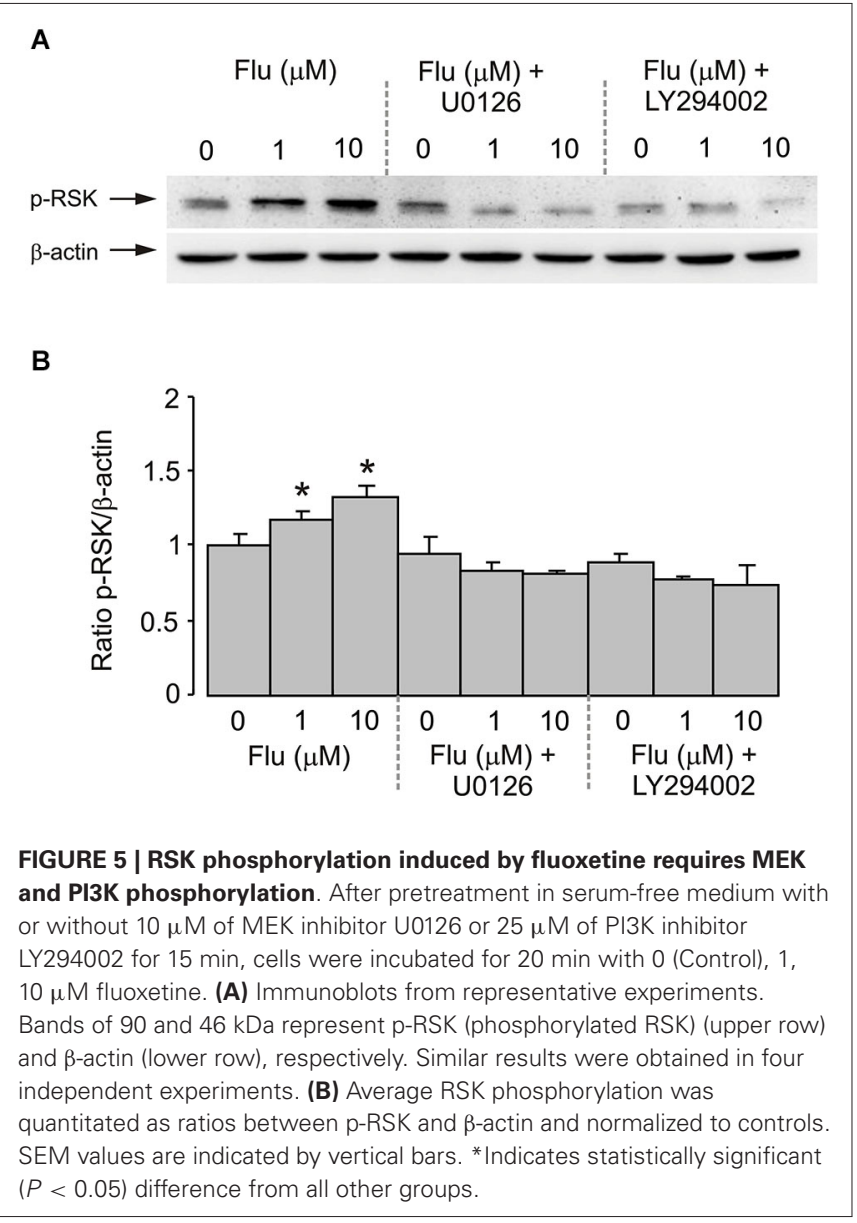

Fluoxetine also stimulates PI3K/AKT signal pathway by EGFR transactivation in astrocytes (Peng and Huang, 2012). The $90 \mathrm{kDa}$ RSK is the downstream effector of $\mathrm{ERK}_{1 / 2}$. The RSK belongs to highly conserved Ser/Thr kinases that are involved in many cellular processes (Anjum and Blenis, 2008), and is also known as a NHE1 kinase (Vik and Ryder, 1997).

We found that fluoxetine at clinically relevant concentrations induced phosphorylation of both $\mathrm{ERK}_{1 / 2}$ and AKT in astrocytes. Conceptually, the PI3K/AKT and Raf/MAPK/ERK $1 / 2$ represent two parallel signal pathways, although, the interactions between PI3K/AKT and Raf/MAPK/ERK $\mathrm{E}_{1 / 2}$ cascades may occur at several different stages and could be either positive or negative. In the present work we found that PI3K/AKT and MAPK/ERK $1 / 2$ signaling potentiated each other (Figure 7). Previously, we reported that either $\mathrm{PI} 3 \mathrm{~K}$ or $\mathrm{AKT}$ may stimulate the activity of Raf, MAPK or $\mathrm{ERK}_{1 / 2}$ in ammonium-induced $\mathrm{ERK}_{1 / 2}$ phosphorylation in astrocytes, since $\mathrm{ERK}_{1 / 2}$ phosphorylation was inhibited by both the MAK inhibitor U0126 and PI3K/AKT inhibitor, LY294002 (Dai et al., 2013). A similar pattern has been observed for effects (i) of insulin or insulin-like growth factor-1 (IGF-1) on skeleton muscle cells (Cross et al., 1994) or insulin receptor-transfected Chinese hamster ovary cells (Welsh et al., 1994); (ii) of platelet-activating factor on guinea pig neutrophils (Ferby et al., 1994); (iii) of interleukin-2 on T-lymphocytes (Karnitz et al., 1995); and (iv) of platelet-derived growth factor
A

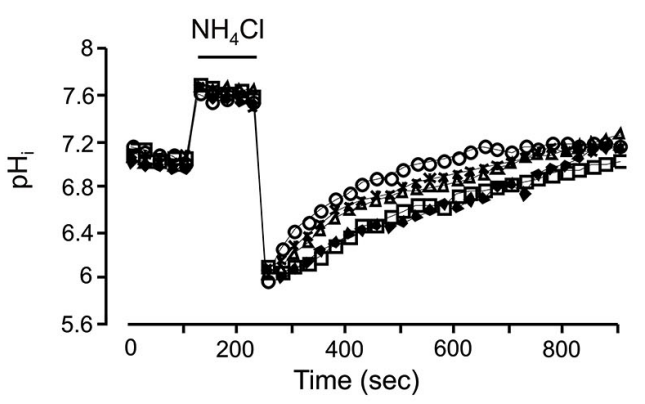

B

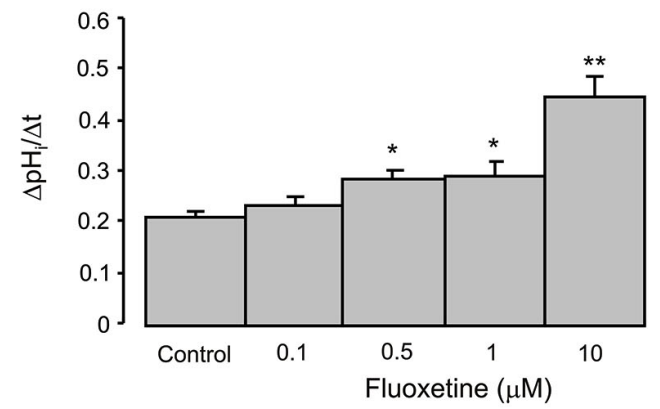

C

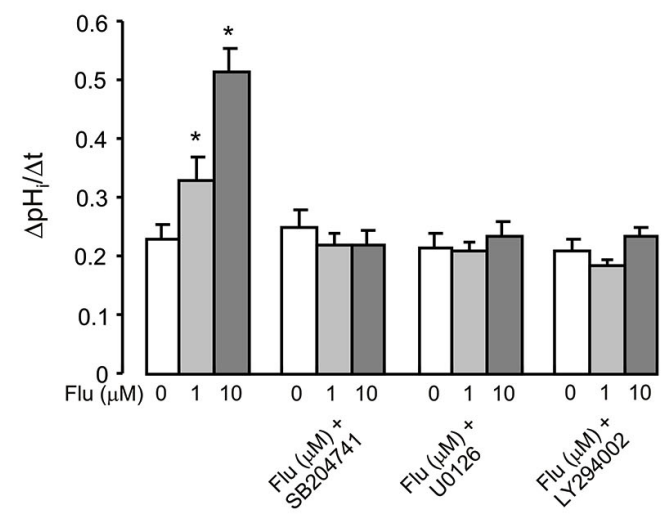

FIGURE 6 | Acute effect of fluoxetine on recovery of $\mathrm{pH}_{i}$ from an acid load in primary cultured of astrocytes, which were exposed to $20 \mathrm{mM}$ $\mathbf{N H}_{4} \mathbf{C l}$ for $\mathbf{2}$ min. (A) A representative experiment showing recovery of $\mathrm{pH}_{i}$ after 20 min of incubation with 0 (control; diamonds), 0.1 (squares), 0.5 (triangles), 1 (asterisks) or $10 \mu \mathrm{M}$ (circles) fluoxetine. (B) Recovery of $\mathrm{pH}_{i}$ is presented as $\Delta \mathrm{pH}_{i} / \Delta \mathrm{t}$. All results are means of $\Delta \mathrm{pH}_{i} / \Delta \mathrm{t}$ of 60 to 120 cells from 4 to 6 coverslips (control, $n=99$ cells from 5 separate coverslips; $0.1 \mu \mathrm{M}$ fluoxetine, $n=77$ cells from 4 coverslips; $0.5 \mu \mathrm{M}$ fluoxetine, $n=60$ cells from 4 separate coverslips; $1 \mu \mathrm{M}$ fluoxetine, $n=72$ cells from 6 separate coverslips; $10 \mu \mathrm{M}$ fluoxetine, $n=120$ cells from 6 separate coverslips). SEM values are indicated by vertical bars. ${ }^{*}$ Indicates statistically significant $(P<0.05)$ difference from control, 0.1 and $10 \mu \mathrm{M}$ groups; **Significant $(P<0.05)$ difference from all other groups. (C) After pretreatment with or without $200 \mathrm{nM}$ of $5-\mathrm{HT}_{2 \mathrm{~B}}$ receptor antagonist SB204741, $10 \mu \mathrm{M}$ of MEK inhibitor U0126 or $25 \mu \mathrm{M}$ of PI3K inhibitor LY294002 for $15 \mathrm{~min}$, cells were incubated for $20 \mathrm{~min}$ with 0 (Control), 1 , $10 \mu \mathrm{M}$ fluoxetine. Recovery of $\mathrm{pH}_{i}$ is presnetd as $\Delta \mathrm{pH}_{i} / \Delta \mathrm{t}$. All results are means of $\Delta \mathrm{pH}_{i} / \Delta \mathrm{t}$ of 36 to 90 cells from 3 to 5 coverslips (control, $n=90$ cells from 5 separate coverslips; $1 \mu \mathrm{M}$ fluoxetine, $n=90$ cells from 5 separate coverslips; $10 \mu \mathrm{M}$ fluoxetine, $n=90$ cells from 5 separate coverslips; SB204741, $n=58$ cells from 3 separate coverslips; SB204741 plus $1 \mu \mathrm{M}$ fluoxetine, $n=75$ cells from 4 separate coverslips; SB204741

(Continued) 


\section{FIGURE 6 | Continued}

plus $10 \mu \mathrm{M}$ fluoxetine, $n=65$ cells from 3 separate coverslips; U0126, $n=43$ cells from 3 separate coverslips; U0126 plus $1 \mu \mathrm{M}$ fluoxetine, $n=48$ cells from 3 separate coverslips; U0126 plus $10 \mu \mathrm{M}$ fluoxetine, $n=36$ cells from 3 separate coverslips; LY294002, $n=82$ cells from 5 separate coverslips; LY294002 plus $1 \mu \mathrm{M}$ fluoxetine, $n=82$ cells from 5 separate coverslips; LY294002 plus $10 \mu \mathrm{M}$ fluoxetine, $n=88$ cells from 5 separate coverslips). SEM values are indicated by vertical bars. *Indicates statistically significant $(P<0.05)$ difference from all other groups.

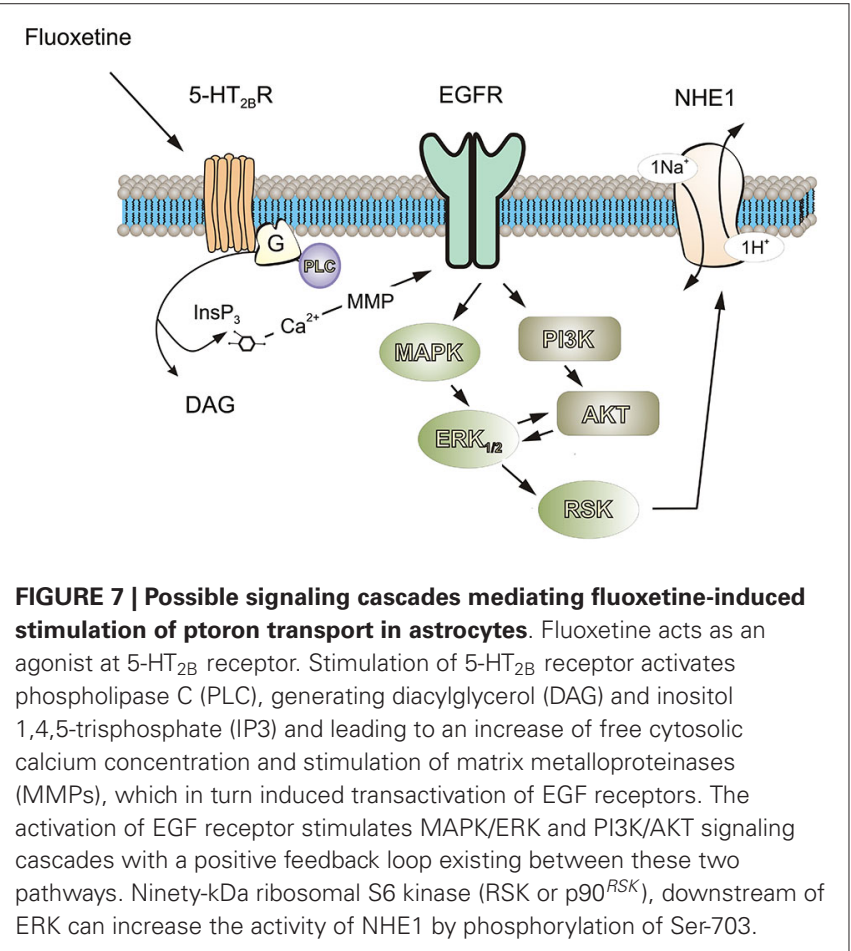

on fibroblasts and T-lymphocytes (Grammer and Blenis, 1997). Although PI3K is one of the major downstream signals of RAS small GTPases (Castellano and Downward, 2011), there is also evidence that PI3K activates MAPK/ERK $1 / 2$ pathway at/or upstream of RAS (Hawes et al., 1996). To the best of our knowledge, our finding is the first report that MAPK/ERK $1 / 2$ potentiates the $\mathrm{PI} 3 \mathrm{~K} / \mathrm{AKT}$ signaling pathway.

The $\mathrm{pH}_{i}$ increases in astrocytes chronically treated with fluoxetine in a time- and concentration-dependent manner. This reflects changes in $\mathrm{pH}$ homeostasis that may influence brain $\mathrm{pH}$ and astrocytic functions and may contribute to the drug action. Changes in $\mathrm{pH}_{i}$ significantly affects astroglial physiology. Addition of lactate acid or a decrease of $\mathrm{pH}_{i}$ inhibits communications through gap junction and facilitates internalization of Cx43 in astrocytes (Anders, 1988; Duffy et al., 2004). Astrocytic proliferation is also regulated by changes in $\mathrm{pH}_{i}$ (Pappas et al., 1994). A decrease in $\mathrm{pH}_{i}$, for instance, inhibited conversion of inactive phosphorylase $\mathrm{b}$ to active phosphorylase a, thus decreasing glycogenolysis (Danforth, 1965). In the brain, glycogen is located almost exclusively in astrocytes (Ibrahim, 1975); glycogen is rapidly consumed along with enhanced neuronal activity (for example during whisker stimulation)
(Swanson et al., 1992), this process contributing to neuronal energetics. The glycogenolysis is similarly important for many signaling processes in astrocytes (Hertz et al., 2015). It is ideal for such a role because it does not require phosphorylation (Hertz et al., 2007); and it is regulated by physiological signals including $\left[\mathrm{Ca}^{2+}\right]_{i}$ rises (Ozawa, 1972) by various transmitters and by increases in extracellular $\mathrm{K}^{+}$concentration (Hof et al., 1988; Magistretti, 1988; Obel et al., 2012). Astroglial release of ATP release stimulated by high $\mathrm{K}^{+}$, glutamate and adenosine is also dependent on glycogenolysis (Xu et al., 2014). In summary, fluoxetine-induced intracellular alkalization may benefit astrocytic gap junction and signal transduction. It will be interesting to know whether these astrocytic functions are deregulated in depressed animals.

\section{AUTHOR AND CONTRIBUTORS}

LP conceived and designed experiments; JR, DS, QB collected and analyzed the data; LP and AV interpreted the data and wrote the paper. All authors commented on the manuscript and have approved the final version.

\section{ACKNOWLEDGMENTS}

This study was supported by Grants No. 31440048 to LP and No. 31400925 to DS from the National Natural Science Foundation of China. AV was supported in part by the grant (agreement from August 272013 No. 02.B.49.21.0003) between The Ministry of Education and Science of the Russian Federation and Lobachevsky State University of Nizhny Novgorod and by the grant of the Russian Scientific Foundation No.14-15-00633.

\section{REFERENCES}

Anders, J. J. (1988). Lactic acid inhibition of gap junctional intercellular communication in in vitro astrocytes as measured by fluorescence recovery after laser photobleaching. Glia 1, 371-379. doi: 10.1002/glia.440010604

Anjum, R., and Blenis, J. (2008). The RSK family of kinases: emerging roles in cellular signalling. Nat. Rev. Mol. Cell Biol. 9, 747-758. doi: 10.1038/nrm2509

Barley, K., Dracheva, S., and Byne, W. (2009). Subcortical oligodendrocyte- and astrocyte-associated gene expression in subjects with schizophrenia, major depression and bipolar disorder. Schizophr. Res. 112, 54-64. doi: 10.1016/j. schres.2009.04.019

Boedtkjer, E., Bunch, L., and Pedersen, S. F. (2012). Physiology, pharmacology and pathophysiology of the $\mathrm{pH}$ regulatory transport proteins NHE1 and NBCn1: similarities, differences and implications for cancer therapy. Curr. Pharm. Des. 18, 1345-1371. doi: 10.2174/138161212799504830

Boron, W. F., and De Weer, P. (1976). Active proton transport stimulated by $\mathrm{CO}_{2} / \mathrm{HCO}_{3}{ }^{-}$, blocked by cyanide. Nature $259,240-241$. doi: 10.1038/259240a0

Castellano, E., and Downward, J. (2011). RAS interaction with PI3K: more than just another effector pathway. Genes Cancer 2, 261-274. doi: 10. 1177/1947601911408079

Cross, D. A., Alessi, D. R., Vandenheede, J. R., McDowell, H. E., Hundal, H. S., and Cohen, P. (1994). The inhibition of glycogen synthase kinase-3 by insulin or insulin-like growth factor 1 in the rat skeletal muscle cell line L6 is blocked by wortmannin, but not by rapamycin: evidence that wortmannin blocks activation of the mitogen-activated protein kinase pathway in L6 cells between Ras and Raf. Biochem. J. 303(Pt. 1), 21-26.

Dai, H., Song, D., Xu, J., Li, B., Hertz, L., and Peng, L. (2013). Ammonia-induced $\mathrm{Na}, \mathrm{K}-\mathrm{ATP}$ ase/ouabain-mediated EGF receptor transactivation, MAPK/ERK and PI3K/AKT signaling and ROS formation cause astrocyte swelling. Neurochem. Int. 63, 610-625. doi: 10.1016/j.neuint.2013.09.005

Danforth, W. H. (1965). Glycogen synthetase activity in skeletal muscle. interconversion of two forms and control of glycogen synthesis. J. Biol. Chem. $240,588-593$. 
Deitmer, J. W., and Chesler, M. (2009). "Neuron-glia pH regulation," in New Encyclopedia of Neuroscience, ed L. R. Squire (Oxford: Academic Press), 739-747.

Deitmer, J. W., and Rose, C. R. (2010). Ion changes and signalling in perisynaptic glia. Brain Res. Rev. 63, 113-129. doi: 10.1016/j.brainresrev.2009. 10.006

Duffy, H. S., Ashton, A. W., O’Donnell, P., Coombs, W., Taffet, S. M., Delmar, M., et al. (2004). Regulation of connexin 43 protein complexes by intracellular acidification. Circ. Res. 94, 215-222. doi: 10.1161/01.res.0000113924.06 926.11

Ferby, I. M., Waga, I., Sakanaka, C., Kume, K., and Shimizu, T. (1994). Wortmannin inhibits mitogen-activated protein kinase activation induced by platelet-activating factor in guinea pig neutrophils. J. Biol. Chem. 269, 30485-30488.

Grammer, T. C., and Blenis, J. (1997). Evidence for MEK-independent pathways regulating the prolonged activation of the ERK-MAP kinases. Oncogene 14, 1635-1642. doi: 10.1038/sj.onc. 1201000

Grant, R. L., and Acosta, D. (1997). Ratiometric measurement of intracellular pH of cultured cells with BCECF in a fluorescence multi-well plate reader. In Vitro Cell. Dev. Biol. Anim. 33, 256-260. doi: 10.1007/s11626-997-0044-z

Hamakawa, H., Murashita, J., Yamada, N., Inubushi, T., Kato, N., and Kato, T. (2004). Reduced intracellular $\mathrm{pH}$ in the basal ganglia and whole brain measured by 31P-MRS in bipolar disorder. Psychiatry Clin. Neurosci. 58, 82-88. doi: 10. 1111/j.1440-1819.2004.01197.x

Hawes, B. E., Luttrell, L. M., van Biesen, T., and Lefkowitz, R. J. (1996). Phosphatidylinositol 3-kinase is an early intermediate in the $\mathrm{G}$ beta gammamediated mitogen-activated protein kinase signaling pathway. J. Biol. Chem. 271, 12133-12136. doi: 10.1074/jbc.271.21.12133

Hertz, L. (2012). Isotope-based quantitation of uptake, release and metabolism of glutamate and glucose in cultured astrocytes. Methods Mol. Biol. 814, 305-323. doi: 10.1007/978-1-61779-452-0_20

Hertz, L., Peng, L., and Dienel, G. A. (2007). Energy metabolism in astrocytes: high rate of oxidative metabolism and spatiotemporal dependence on glycolysis/glycogenolysis. J. Cereb. Blood Flow Metab. 27, 219-249. doi: 10. 1038/sj.jcbfm. 9600343

Hertz, L., Peng, L., and Lai, J. C. (1998). Astrocytic glycogenolysis: mechanisms and functions. Methods 16, 293-310. doi: 10.1006/meth.1998.0686

Hertz, L., Xu, J., Song, D., Du, T., Li, B., Yan, E., et al. (2015). Astrocytic glycogenolysis: mechanisms and functions. Metab. Brain Dis. 30, 317-333. doi: 10.1007/s11011-014-9536-1

Hof, P. R., Pascale, E., and Magistretti, P. J. (1988). $\mathrm{K}^{+}$at concentrations reached in the extracellular space during neuronal activity promotes a $\mathrm{Ca}^{2+}$. dependent glycogen hydrolysis in mouse cerebral cortex. J. Neurosci. 8, 19221928.

Ibrahim, M. Z. (1975). Glycogen and its related enzymes of metabolism in the central nervous system. Adv. Anat. Embryol. Cell Biol. 52, 3-89.

Iwanaga, K., Sakurai, M., Minami, T., Kato, Y., Sairyo, K., and Kikuchi, Y. (1996). Is the intracellular $\mathrm{pH}$ threshold an anaerobic threshold from the view point of intracellular events?: a brief review. Appl. Human Sci. 15, 59-65. doi: 10. 2114/jpa.15.59

Karnitz, L. M., Burns, L. A., Sutor, S. L., Blenis, J., and Abraham, R. T. (1995), Interleukin-2 triggers a novel phosphatidylinositol 3-kinase-dependent MEK activation pathway. Mol. Cell Biol. 15, 3049-3057.

Kato, T., Inubushi, T., and Kato, N. (1998). Magnetic resonance spectroscopy in affective disorders. J. Neuropsychiatry Clin. Neurosci. 10, 133-147. doi: 10. 1007/978-4-431-68479-4_10

Kato, T., Takahashi, S., Shioiri, T., Murashita, J., Hamakawa, H., and Inubushi, T. (1994). Reduction of brain phosphocreatine in bipolar II disorder detected by phosphorus-31 magnetic resonance spectroscopy. J. Affect. Disord. 31, 125-133. doi: 10.1016/0165-0327(94)90116-3

Katsura, K., and Siesjo, B. (1998). "Acid-base metabolism in ischemia," in $p H$ and Brain Function, eds K. Kaila and B. Ransom (New York: Wiley-Liss, Inc), 563-582.

Kirischuk, S., Parpura, V., and Verkhratsky, A. (2012). Sodium dynamics: another key to astroglial excitability? Trends Neurosci. 35, 497-506. doi: 10.1016/j.tins. 2012.04.003

Klempan, T. A., Sequeira, A., Canetti, L., Lalovic, A., Ernst, C., ffrench-Mullen, J., et al. (2009). Altered expression of genes involved in ATP biosynthesis and GABAergic neurotransmission in the ventral prefrontal cortex of suicides with and without major depression. Mol. Psychiatry 14, 175-189. doi: 10.1038/sj.mp. 4002110

Kong, E. K., Peng, L., Chen, Y., Yu, A. C., and Hertz, L. (2002). Up-regulation of $5-\mathrm{HT}_{2 \mathrm{~B}}$ receptor density and receptor-mediated glycogenolysis in mouse astrocytes by long-term fluoxetine administration. Neurochem. Res. 27, 113-120. doi: 10.1023/A:1014862808126

Lange, S. C., Bak, L. K., Waagepetersen, H. S., Schousboe, A., and Norenberg, M. D. (2012). Primary cultures of astrocytes: their value in understanding astrocytes in health and disease. Neurochem. Res. 37, 2569-2588. doi: 10.1007/s11064-0120868-0

Li, B., Dong, L., Wang, B., Cai, L., Jiang, N., and Peng, L. (2012a). Cell type-specific gene expression and editing responses to chronic fluoxetine treatment in the in vivo mouse brain and their relevance for stress-induced anhedonia. Neurochem. Res. 37, 2480-2495. doi: 10.1007/s11064-012-0814-1

Li, B., Hertz, L., and Peng, L. (2012b). Aralar mRNA and protein levels in neurons and astrocytes freshly isolated from young and adult mouse brain and in maturing cultured astrocytes. Neurochem. Int. 61, 1325-1332. doi: 10.1016/j. neuint.2012.09.009

Li, B., Zhang, S., Li, M., Zhang, H., Hertz, L., and Peng, L. (2009). Down-regulation of GluK2 kainate receptor expression by chronic treatment with moodstabilizing anti-convulsants or lithium in cultured astrocytes and brain, but not in neurons. Neuropharmacology 57, 375-385. doi: 10.1016/j.neuropharm.2009. 07.004

Li, B., Zhang, S., Zhang, H., Nu, W., Cai, L., Hertz, L., et al. (2008). Fluoxetinemediated $5-\mathrm{HT}_{2 \mathrm{~B}}$ receptor stimulation in astrocytes causes EGF receptor transactivation and ERK phosphorylation. Psychopharmacology (Berl) 201, 443-458. doi: 10.1007/s00213-008-1306-5

Lowry, O. H., Rosebrough, N. J., Farr, A. L., and Randall, R. J. (1951). Protein measurement with the Folin phenol reagent. J. Biol. Chem. 193, 265-275.

Luo, J., Kintner, D. B., Shull, G. E., and Sun, D. (2007). ERK1/2-p90 RSKmediated phosphorylation of $\mathrm{Na}^{+} / \mathrm{H}^{+}$exchanger isoform 1 . A role in ischemic neuronal death. J. Biol. Chem. 282, 28274-28284. doi: 10.1074/jbc.m7023 73200

Magistretti, P. J. (1988). Regulation of glycogenolysis by neurotransmitters in the central nervous system. Diabete Metab. 14, 237-246.

Manning, T. J. Jr., and Sontheimer, H. (1999). Recording of intracellular $\mathrm{Ca}^{2+}$, $\mathrm{Cl}^{-}, \mathrm{pH}$ and membrane potential in cultured astrocytes using a fluorescence plate reader. J. Neurosci. Methods 91, 73-81. doi: 10.1016/s0165-0270(99) 00083-7

McAlear, S. D., and Bevensee, M. O. (2004). "pH regulation in non-neuronal brain cells and interstitial fluid," in Non-Neuronal Cells of the Nervous System: Function and Dysfunction, ed L. Hertz (Amsterdam: Elsevier), 707-745.

McNally, L., Bhagwagar, Z., and Hannestad, J. (2008). Inflammation, glutamate and glia in depression: a literature review. CNS Spectr. 13, 501-510.

Meier, E., Hertz, L., and Schousboe, A. (1991). Neurotransmitters as developmental signals. Neurochem. Int. 19, 1-15. doi: 10.1016/0197-0186(91) 90113-r

Moor, A. N., and Fliegel, L. (1999). Protein kinase-mediated regulation of the $\mathrm{Na}^{+} / \mathrm{H}^{+}$exchanger in the rat myocardium by mitogen-activated protein kinasedependent pathways. J. Biol. Chem. 274, 22985-22992. doi: 10.1074/jbc.274.33. 22985

Obel, L. F., Müller, M. S., Walls, A. B., Sickmann, H. M., Bak, L. K., Waagepetersen, H. S., et al. (2012). Brain glycogen-new perspectives on its metabolic function and regulation at the subcellular level. Front. Neuroenergetics 4:3. doi: 10. 3389/fnene.2012.00003

Ozawa, E. (1972). Activation of muscular phosphorylase b kinase by a minute amount of Ca ion. J. Biochem. 71, 321-331.

Pappas, C. A., Ullrich, N., and Sontheimer, H. (1994). Reduction of glial proliferation by $\mathrm{K}^{+}$channel blockers is mediated by changes in $\mathrm{pH}_{i}$. Neuroreport 6, 193-196. doi: 10.1097/00001756-199412300-00049

Peng, L., and Huang, J. (2012). Astrocytic $5-\mathrm{HT}_{2 \mathrm{~B}}$ receptor as in vitro and in vivo target of SSRIs. Recent Pat. CNS Drug Discov. 7, 243-253. doi: 10. 2174/157488912803252078

Rajkowska, G., and Miguel-Hidalgo, J. J. (2007). Gliogenesis and glial pathology in depression. CNS Neurol. Disord. Drug Targets 6, 219-233. doi: 10. 2174/187152707780619326

Rajkowska, G., and Stockmeier, C. A. (2013). Astrocyte pathology in major depressive disorder: insights from human postmortem brain tissue. Curr. Drug Targets 14, 1225-1236. doi: 10.2174/13894501113149990156 
Rose, C. R., and Karus, C. (2013). Two sides of the same coin: sodium homeostasis and signaling in astrocytes under physiological and pathophysiological conditions. Glia 61, 1191-1205. doi: 10.1002/glia.22492

Rose, C. F., Verkhratsky, A., and Parpura, V. (2013). Astrocyte glutamine synthetase: pivotal in health and disease. Biochem. Soc. Trans. 41, 1518-1524. doi: 10. 1042/BST20130237

Snabaitis, A. K., D’Mello, R., Dashnyam, S., and Avkiran, M. (2006). A novel role for protein phosphatase $2 \mathrm{~A}$ in receptor-mediated regulation of the cardiac sarcolemmal Na $\mathrm{Na}^{+} / \mathrm{H}^{+}$exchanger NHE1. J. Biol. Chem. 281, 20252-20262. doi: 10.1074/jbc.m600268200

Song, D., Du, T., Li, B., Cai, L., Gu, L., Li, H., et al. (2008). Astrocytic alkalinization by therapeutically relevant lithium concentrations: implications for myo-inositol depletion. Psychopharmacology (Berl) 200, 187-195. doi: 10. 1007/s00213-008-1194-8

Song, D., Li, B., Yan, E., Man, Y., Wolfson, M., Chen, Y., et al. (2012). Chronic treatment with anti-bipolar drugs causes intracellular alkalinization in astrocytes, altering their functions. Neurochem. Res. 37, 2524-2540. doi: 10. 1007/s11064-012-0837-7

Song, D., Man, Y., Li, B., Xu, J., Hertz, L., and Peng, L. (2013). Comparison between drug-induced and $\mathrm{K}^{+}$-induced changes in molar acid extrusion fluxes $\left(\mathrm{JH}^{+}\right)$ and in energy consumption rates in astrocytes. Neurochem. Res. 38, 2364-2374. doi: 10.1007/s11064-013-1149-2

Swanson, R. A., Morton, M. M., Sagar, S. M., and Sharp, F. R. (1992). Sensory stimulation induces local cerebral glycogenolysis: demonstration by autoradiography. Neuroscience 51, 451-461. doi: 10.1016/0306-4522(92) 90329-z

Verkhratsky, A., Nedergaard, M., and Hertz, L. (2015). Why are astrocytes important? Neurochem. Res. 40, 389-401. doi: 10.1007/s11064-014-1403-2

Verkhratsky, A., Parpura, V., Pekna, M., Pekny, M., and Sofroniew, M. (2014a). Glia in the pathogenesis of neurodegenerative diseases. Biochem. Soc. Trans. 42, 1291-1301. doi: 10.1042/BST20140107

Verkhratsky, A., Rodríguez, J. J., and Parpura, V. (2013). Astroglia in neurological diseases. Future Neurol. 8, 149-158. doi: 10.2217/fnl.12.90
Verkhratsky, A., Rodríguez, J. J., and Steardo, L. (2014b). Astrogliopathology: a central element of neuropsychiatric diseases? Neuroscientist 20, 576-588. doi: 10. $1177 / 1073858413510208$

Vik, T. A., and Ryder, J. W. (1997). Identification of serine 380 as the major site of autophosphorylation of Xenopus pp90rsk. Biochem. Biophys. Res. Commun. 235, 398-402. doi: 10.1006/bbrc.1997.6794

Welsh, G. I., Foulstone, E. J., Young, S. W., Tavaré, J. M., and Proud, C. G. (1994). Wortmannin inhibits the effects of insulin and serum on the activities of glycogen synthase kinase- 3 and mitogen-activated protein kinase. Biochem. J. 303(Pt. 1), 15-20.

Xu, J., Song, D., Bai, Q., Zhou, L., Cai, L., Hertz, L., et al. (2014). Role of glycogenolysis in stimulation of ATP release from cultured mouse astrocytes by transmitters and high $\mathrm{K}^{+}$concentrations. ASN Neuro. 6:e00132. doi: 10 . 1042/AN20130040

Conflict of Interest Statement: The authors declare that the research was conducted in the absence of any commercial or financial relationships that could be construed as a potential conflict of interest.

Received: 24 January 2015; accepted: 10 February 2015; published online: 03 March 2015.

Citation: Ren J, Song D, Bai Q, Verkhratsky A and Peng L (2015) Fluoxetine induces alkalinization of astroglial cytosol through stimulation of sodium-hydrogen exchanger 1: dissection of intracellular signaling pathways. Front. Cell. Neurosci. 9:61. doi: 10.3389/fncel.2015.00061

This article was submitted to the journal Frontiers in Cellular Neuroscience.

Copyright (c) 2015 Ren, Song, Bai, Verkhratsky and Peng. This is an open-access article distributed under the terms of the Creative Commons Attribution License (CC BY). The use, distribution and reproduction in other forums is permitted, provided the original author(s) or licensor are credited and that the original publication in this journal is cited, in accordance with accepted academic practice. No use, distribution or reproduction is permitted which does not comply with these terms. 